\title{
ROMAN INGARDEN'S CONTRIBUTION TO SOLVING THE ONTOLOGICAL AND METHODOLOGICAL PROBLEMS OF PHENOMENOLOGY OF MUSIC
}

\author{
ANASTASIA MEDOVA \\ DSc in Philosophy, Professor. \\ Reshetnev Siberian State University of Science \& Technology. \\ Krasnoyarsk State Pedagogical University named after V. P. Astafyev. \\ 660049 Krasnoyarsk, Russian Federation. \\ E-mail: medova@sibsau.ru
}

\section{ANNA KIRICHENKO}

Senior Lecturer.

Pavlov University.

197022 St. Petersburg, Russian Federation.

E-mail: askalon_@mail.ru

Phenomenology of music has been a perspective trend of phenomenological aesthetics for more than a hundred years. The topic of the paper is fixation the main problems and vectors of development of phenomenology of music. The authors execute an analysis of Roman Ingarden's position in the discussions concerning the methodological and ontological problems of phenomenology of music. The paper aims at revealing succession in Roman Ingarden's solutions to the phenomenology of music problems. The other aim is reflection on the originality of Ingarden's ideas in the context of phenomenological interpretations of music in $20^{\text {th }}$ and $21^{\text {st }}$ centuries. The solution to these tasks allows the authors to fix key problems and identify the principal positions of phenomenology of music. The main sources of the comparative and historical analysis are the studies carried out by Husserl, Sartre, Merleau-Ponty, Clifton, and Ihde. The most important ontological problems of phenomenology of music are: spatiotemporal constitution of music, reduction of a work of music to its performance, and ontological status of a work of music. The analysis of Ingarden's position on these problems allows us to characterize it as something different from the existing versions. According to the conception, the time of music is a special type of time, that is, quasi-time. A piece of music is a purely intentional, heteronomous, and intersubjective object. There are a number of methodological specificities of Ingarden's approach: a refusal of reduction of musical theoretical data, a tendency for independence of a piece of music from

(C) ANASTASIA MEDOVA, ANNA KIRICHENKO, 2020 
conscious and mental processes, and an interpretation of a piece of music as a non-sounding phenomenon. In conclusion, the authors demonstrate how the originality and radical nature of Ingarden's conclusions made his position defenseless against critique and simultaneously marked the tendency in the contemporary phenomenological studies of music.

Key words: Roman Ingarden, ontology of music, acoustic phenomenon, musical time, space of music, bound idealities, intentional object, quasitemporal structure, semantic intention.

\section{ВКЛАД РОМАНА ИНГАРДЕНА В РЕШЕНИЕ ОНТОЛОГИЧЕСКИХ И МЕТОДОЛОГИЧЕСКИХ ПРОБЛЕМ ФЕНОМЕНОЛОГИИ МУЗЫКИ}

\section{АНАСТАСИЯ МЕДОВА}

Доктор философских наук, профессор.

Сибирский государственный университет науки и технологий имени академика М. Ф. Решетнева. Красноярский государственный педагогический университет имени В. П. Астафьева. 660049 Красноярск, Россия.

E-mail:medova@sibsau.ru

\section{АННА КИРИЧЕНКО}

Старший преподаватель.

Первый Санкт-Петербургский государственный медицинский университет имени И.П. Павлова. 197022 Санкт-Петербург, Россия.

E-mail: askalon_@mail.ru

Феноменология музыки является перспективным трендом феноменологической эстетики на протяжении более ста лет. Статья посвящена рассмотрению основных проблем и векторов развития феноменологии музыки. Авторы анализируют позицию Романа Ингардена в рамках дискуссий, касающихся методологических и онтологических проблем феноменологии музыки. Статья нацелена на раскрытие последовательности в решении основных проблем феноменологии музыки у Романа Ингардена. Другой целью статьи является осмысление оригинальности идей Ингардена в контексте феноменологических интерпретаций музыки в 20-21 вв. Решение этих задач позволяет авторам зафиксировать ключевые проблемы и выявить принципиальные позиции в феноменологии музыки. Основными источниками компаративного и исторического анализа являются исследования, проведенные Гуссерлем, Сартром, Мерло-Понти, Клифтоном и Иде. Важнейшими онтологическими проблемами феноменологии музыки являются пространственно-временная конституция музыки, редукция музыкального произведения к его исполнению и онтологический статус музыкального произведения. Анализ позиции Ингардена относительно этих проблем позволяет нам обозначить ее отличие от современных подходов. Согласно концепции Ингардена, музыкальное время является временем особого рода, т. е. квази-временем. Музыкальное произведение - это чисто интенциональный, гетерономный и интерсубъективный объект. Подходу Ингардена присущ целый ряд методологических особенностей: отказ от редукции музыкальных теорий, установка на независимость музыкального произведения от сознательных и ментальных процессов, интерпретация музыкального произведения как неакустического феномена. В заключение авторы демонстрируют, как оригинальность и радикальность выводов Ингардена сделала 
его позицию беззащитной перед лицом критики и одновременно стала тенденцией в современных феноменологических исследованиях музыки.

Ключевые слова: Роман Ингарден, онтология музыки, акустический феномен, музыкальное время, пространство музыки, связанные идеальности, интенциональный объект, квазитемпоральная структура, семантическая интенция.

\section{INTRODUCTION}

On one hand, phenomenological aesthetics is a significant trend in philosophy that has developed considerably since the beginning of the $20^{\text {th }}$ century; on the other hand, many problems of its specificity and methodology remain open and even controversial. One of the major concerns of this field is phenomenology of music, which starts from Der ästhetische Gegenstand. Eine phänomenologische Studie, written in 1908 by Waldemar Conrad, who was a student and follower of Husserl in Göttingen. Many researchers have studied the problems of phenomenology of music over the course of the more than one hundred years of its evolution, but only a few of them have written works that reflect exclusively on the topic. Among them, besides W. Conrad, we can mention thinkers such as M. Dufrenne, A. Schütz, R. Ingarden, T. Clifton, L. Ferrara, and D. Ihde.

Roman Ingarden's works on the analysis of art are commonly recognized as examples of phenomenological aesthetics. While his studies on works of literature have had the most considerable impact, Ingarden repeatedly refers to the problem of the comprehension of music throughout his oeuvre (Ingarden, 1955; Ingarden, 1962). Among his few works on philosophy dedicated entirely to music, The Work of Music and the Problem of its Identity (Utwór muzyczny i sprawa jego tożsamości)—published in Polish after his death in 1973-is particularly important. This text was both the culmination of the philosopher's aesthetic investigations up to that point and the starting point for his future studies in phenomenological aesthetics.

The aim of this paper is to reflect upon Ingarden's contribution to solving fundamental problems in the development of phenomenology of music. These problems can be divided into three groups: methodological, ontological and eidetic, i.e. those related to the specifics of the constitution of musical phenomena as a result of eidetic reduction. We will examine key aspects of the first two groups of problems and retrace their attempted solutions, starting from theories preceding Ingarden's aesthetics up to those of the present. We are interested in the succession of Ingarden's position from that of Husserl to those of French phenomenologists, who were his contemporaries, most of all, Sartre. We will then point out Ingarden's originality in the context of the 
evolution of the phenomenological comprehension of music. Finally the authors will address the consequences of Ingarden's conception of the development of phenomenology of music.

\section{INGARDEN'S SOLUTION TO THE METHODOLOGICAL PROBLEMS OF MUSIC. PHENOMENOLOGY OF MUSIC}

The corpus of methodological problems of phenomenology of music is organized around issues concerning the procedure of phenomenological investigation. The common point of departure on this matter is Husserl's program of phenomenological analysis as established in Logische Untersuchungen and later clarified in Ideen zu einer reinen Phänomenologie und phänomenologischen Philosophie. However, every phenomenologist solves a number of methodological problems as applied to the study of specific pieces of music, therein adjusting his study program according to the ultimate goals of his research. Some of the relevant issues in this field are; what kind of acoustic data should we analyze in the process of phenomenological research of music (pitch of tones, timbres, harmonies, dynamic nuances etc.) and what we should subject to reduction. The problems are how to fix and process the obtained data, whether we should only resort to introspection or draw from data provided by other listeners, etc. Phenomenological investigation may imply developing a descriptive methodology for every piece of music just as modern composers create a new musical language for each piece of music they write.

Roman Ingarden's methodological principles are determined by the common task of his musical studies - to reveal the unique ways in which a piece of music exists insofar as it is perceived as an intersubjective intentional object. The specific features of his method are as follows:

1. Focus only on pieces of classical music such as those by Chopin and Beethoven. Ingarden deliberately ignores non-academic and experimental forms in order to concentrate his efforts on examples of music itself, i.e. classical non-programmatic instrumental music.

2. Draw upon both musical and theoretical data. Thus, Ingarden does not carry out an reduction. He doesn't underestimate scientific data; he doesn't reduce regional ontologies to work his way to the pure phenomenal nature of music as it reveals itself in consciousness.

3. A shift from the constitutive process of music in consciousness to the being of music itself. Ingarden analyzes a piece of music as something independent of perception, mental activity and cognitive processes. 
4. Elimination of musical semantics, reduction of expressive and signifying intentions of pure non-programmatic music, which rejects the idea of their being an ontological connection between a piece of music and its score (Ingarden, 1986, 47, 37-38).

5. The analytical attitude towards music as a non-sounding phenomenon. That position is implicit but it is followed by a number of Ingarden's theses:

1) pieces of music do not exist as physical phenomena in continuity with the real world; they are not acoustic phenomena (Ingarden, 1986, 2-3, 5, 10);

2) a piece of music is not its performance; it continues to exist even if no one performs it;

3) a piece of music is not a part of anybody's psychic life; it is not a composer's or listeners' conscious experiences, i.e. a piece of music is not a set of acoustic representations (Ingarden, 1986, 2-3, 32-33);

4) there are the non-sounding elements such as temporal structure, inner movement, the "forms" of sound constructions, and their emotional properties (Ingarden, 1986, chapter 5).

Ingarden is inclined to perceive music not only as sounding phenomena but as non-sounding phenomena as well. This aspect of his study is extremely interesting and demands special study. Here we restrict ourselves to only a few comments. It would be wrong to say that Ingarden disregards the acoustic nature of music. At the same time, it is worth mentioning several subtle remarks, which show that he treats the structure of music as accomplished beyond the acoustic data both of a composer's consciousness and of a listener's. The first remark concerns Ingarden's statement of the relationship between a piece of music and its score. He introduces the notion of "lowest proprieties" which concerns the qualities of musical sound that are not fixed in a score.

One may legitimately doubt whether a musical work is in every respect univocally and ultimately determined by its "lowest" properties that cannot be further differentiated. [...]. This applies for example to the tonal coloring which forms part of the work. The score prescribes simply the kind of instrument on which the work is to be performed, therefore indirectly determining the type of tonal coloring, but not the lowest variant of that type, that absolutely individual coloring which is realized only in a certain performance. The same applies to the fullness of tones or sounds that is strictly connected with the tonal coloring. To a certain extent the same problem arises with reference to the absolute pitch of the notes. (Ingarden, 1986, 21-22)

These observations lead Ingarden to the following statement: “There is a 'sphere of irrelevance' within musical works and perhaps in all works of art. [...]. It appears 
that this is possible only when the work itself is not in every respect univocally determined by the lowest qualities" (Ingarden, 1986, 23). The lowest qualities that Ingarden discusses are the ultimate specificity of musical sounding. When we listen to music, these are the very qualities that we hear. Those are the only qualities acceptable to the audial experience. But Ingarden says that a work of music is not exclusively determined by these qualities alone. Already at this stage of his research, we see him formulating the idea that not only sounds, but non-sounding elements allow for the possibility of hearing music.

In the fourth chapter of "The Work of Music and the Problem of its Identity," Ingarden explicitly states this idea. From the quotation given below, we understand that he considers the non-sounding basis to be a structural element of music that is inseparable from its sounding "surface" but that, at the same time, determines the uniqueness of its specific and supra-temporal musical unity.

[...] I will endeavor to show that it is the various nonsounding elements in musical compositions that play the chief role in musical 'beauty'. They do not form separate strata in the work, nor in particular do they constitute a distinct stratum in relation to what constitutes sound, or a certain structured cluster of sounds. They are so closely tied to sounds and sound-constructs that the musical work forms an extremely compact and cohesive whole and in this respect outshines work in the other arts, especially literature. (Ingarden, 1986, 51)

Ingarden studies the constitutional basis of music so profoundly and carefully that he is able to discern the non-sounding and non-acoustic elements of music. If we miss this distinction, it may seem that Ingarden contradicts himself when he says that: "We have seen the failure of various attempts at pointing to some new, and in particular nonacoustic element of a musical work, to differentiate it from acoustic signals and sound phenomena in nature" (Ingarden, 1986, 48).

A short survey of Ingarden's methodology shows that on one hand, his approach is very close to Husserl's phenomenological program. His analysis can be characterized as transcendental insofar as he takes a musical opus to be constituted as a correlate of pure consciousness, as the phenomenological analysis it demands. It is associated with Ingarden's attitude to the acoustic nature of a piece of music: "No work is a hic et nunc developing acoustic phenomenon, as it would have to be to undergo change resulting from variations in the range of auditory aspects randomly developing in particular listeners" (Ingarden, 1986, 19, original emphasis).

But, on the other hand, Ingarden's methods differ both from classical phenomenology and from other later formulations of phenomenological procedure. Ingarden does not carry out a transcendental and phenomenological reduction and does not 
concentrate foremost on elementary and unaffected data of consciousness. He also does not use the method of eidetic variation or treat constitution as a process which permits a work of music to appear and represent itself.

The originality of Ingarden's method then, which is largely due to his principled stance on Husserl's "transcendental idealism," consists of his criticism of the transcendental reduction. This attitude toward the method of the transcendental reduction marks the main point of disagreement between Ingarden and Husserl in their comprehension of the tasks of phenomenology (Sodeika, 1989). According to Ingarden, the phenomenological reduction is de facto an operation which immediately resolves the problem of the existential relation of the world and other fields of being to pure consciousness. The phenomenological reduction suspends belief in the existence and determination of objects of knowledge. It prevents "prejudging in a positive manner the cognitive validity of the investigated cognition at the moment when this validity is still to be disclosed or evaluated in the very epistemological investigation" (Ingarden, 1975, 39).

Ingarden understands the phenomenological reduction to uncover a separate field of individual being, namely, that of pure consciousness. This is the very field where it is possible to encounter a framework of absolute and indubitable knowledge as obtained in immanent perception. But Ingarden does not follow Husserl's precept, according to which it is impossible to separate a real object from the perception of that object. He rejects this point of view, primarily because he sees concretization as an individual process that varies from one person to another, whereas the work of art remains the same for every perceiving subject. "Further, reducing the art object to the subjectivity of the viewer leads to solipsism, according to Ingarden, and ultimately therefore denies the possibility of ever attaining to knowledge with respect to art objects" (Kocay, 2002, 202). The problem applied to music is far more complicated by the fact that a work of music "is not an ideal object, it does not follow that it is a real object, since the domains of those two concepts do not cover all objects" (Ingarden, 1986, 15).

As Jeff Mitscherling notices, Ingarden had his own "realist rejoinder" to Husserl's approach. It begins with the contrary claim that epistemological investigations may only proceed after completing the fundamental ontological investigation of the objects of cognition. Ingarden responded to Husserl in a way that "the demonstration that even such purely intentional objects as works of art, which everyone recognizes as originating in acts of consciousness, in fact owe their existence to more than these acts of consciousness alone" (Mitscherling, 2012, 436).

All of these points to some extent explain why Ingarden does not apply the phenomenological reduction to music. In spite of this, Ingarden masterfully implements 
the eidetic reduction. He chooses the way of describing and observing a phenomenon again and again until it discloses its essential features. To see an essence, Ingarden employs negative definitions, which brings him to original understanding of music. A piece of music is not an acoustic or mental phenomenon, nor is it a purely phenomenal given, since only the performance of a concrete piece of music can be given directly, not the piece of music itself. Thus, a piece of music is neither its performance nor its score. Music is also not a part of anybody's mental life. It can't be reduced to the conscious experiences of its creator or of its listeners due to the fact that sounds as physical phenomena are entirely transcendental to acoustic-sensitive experiences:

[...] if the data of auditory perception constitute the content of auditorily perceived experiences, then the sounds, tones, chords, and melodic products that we perceive objectively are not the content of auditorily perceived experiences, and therefore, a fortiori, are not the content of any conscious experiences. (Ingarden, 1986, 31)

Ingarden's phenomenological methodology brought him to the paradoxical conclusions explained by his ontological interpretation of a piece of music.

\section{THE ONTOLOGICAL PROBLEMS OF A PHENOMENOLOGICAL STUDY ON MUSIC}

One can point out three problems that have been discussed over the course of the development of phenomenology of music: the spatiotemporal constitution of music, the reduction of a piece of music to its performance and the ontological status of a piece of music.

As for the problem of identifying the spatiotemporal aspects of music, the specifics of temporal syntheses that make music available to consciousness are of the most interest. The concept of time-consciousness, which Husserl developed for his seminars in 1905 and perfected in his other essays, is based on examples of melody.

A set of retentions, protentions, and the retention of the actual present explain the listener's experience of the wholeness of a melody in his consciousness; an experience only characteristic of music. The temporal retentions and 'contractions' of such a broad radius observed during the perception of certain large-scale pieces of music are also of considerable phenomenological interest. The phenomenological tradition of understanding musical time was developed by Roman Ingarden, Alfred Schütz (1976), F. Joseph Smith (1973), Thomas Clifton (1983) and Judy Lochhead (1986). Ingarden also pays considerable attention to describing temporal grasps, though he is more interested not necessarily in how acts of consciousness form an intentional 
correlate of a piece of music, but what kind of causal relationships take place between works of art and facts of the world, in the context of which these works exist. This shows the ontological focus of his phenomenology of music, which is consistent with all of the other areas of the philosopher's work.

The spatial aspects of music are also a significant subject of phenomenological study. Among such spatial aspects are the objective spatial conditions of the existence and perception of a piece of music (Merleau-Ponty, 1962; Clifton, 1983; Ingarden, 1986; Ihde, 2007) and the spatial modus of music in its correlation with corporeality (Dufrenne, 1953; Ferrara, 1984; Ihde, 2007). Researchers also study the "immanent" space, which is spontaneously constituted in audial experience. Due to that spatial intention, musical tones are perceived as high and low, timbres are comprehended as light and heavy, interval chords are perceived as contracted and wide, etc. Don Ihde found that a rearrangement of spatial considerations helped to identify some unnoticed characteristics of music. The spatial modus of the givenness of music is significant insomuch as the visual-spatial imagery cannot be completely rejected in a phenomenological description of music (Christensen, 2012, 7). Reflections upon spatiotemporal moments of music are directly connected with the problem of the ontological status of a piece of music. This is indeed the problem that is most disputed among phenomenologists. Their discussion concerns ultimately of modus of existence of music: whether a piece of music is material, ideal, virtual, intentional, or some other kind of object (Conrad, 1908; Sartre, 1940; Ingarden, 1973; Schütz, 1976; Clifton, 1976; Ihde, 2007; Geniusas, 2018).

The discussion about the ontological status of a piece of music reveal one more problem, which can be formulated as follows: whether a piece of music is equivalent with its performance (Husserl, 1980; Sartre, 1940; Ingarden, 1973; Pryer, 2013; Geniusas, 2018)? In other words, does a piece of music exist without its performance and, consequently, without an auditory perception of it? This purely phenomenological problem is extraneous to the other spheres of music such that music experts, experts on culture and aesthetics and musicians indeed find it perplexing. Ingarden develops this issue through the problem of the identity of a piece of music; the main concern of his effort to comprehend the nature of music.

\section{THE CORRELATION BETWEEN A WORK OF MUSIC AND ITS PERFORMANCE}

In contrast to the perception of visual arts and fiction, it is impossible to directly comprehend a piece of music without its actualization in sound by a performer-intermediary. This feature of music is precisely what necessitates defining the ontological 
and phenomenological relation of a piece of music to its performance. In this regard, the following question is vital for a phenomenologist: what do we hear when we listen to music; physical sounds, a performer's interpretation, audial images, a piece of music itself or something else? This is the starting point of any phenomenological study of music.

Husserl argues that actual performances of musical works are reproductions of the original: "The original is the sonata just as Beethoven meant it. [...] Everyone has his ideal Beethoven. Every artist interprets him differently” (Husserl, 1980, 158). From the point of musical practice and common sense, Husserl's statement is rather trivial but in the context of phenomenological study it results in a paradox. Geniusas formulates this paradox as follows:

It is exactly what I never really hear - the ideal work itself - that plays the normative role in my act of aesthetic listening and thus stamps each and every performance as a more or less adequate presentation of the work itself. (Geniusas, 2018, 240)

Nevertheless, Sartre develops Husserl's position. He claims, for instance, that the performance of the Seventh Symphony by Beethoven is its own analogon. A work of music can be manifested only through analogons that unfurl over time. But in order to grasp a piece of music by these analogons, it is necessary to conduct the imaging reduction, which is to say, to precisely apprehend the real sounds as analogons (Sartre, 2004, 193).

The necessity for music to sound and to be performed conceals many paradoxes. Ingarden's greatest interest was the contradictions of the identity of a musical opus. One and the same piece of music can be performed by different musicians many times and simultaneously in different places but none of these facts cause the piece of music itself to lose its uniqueness. Various performances of one and the same piece of music do not need to be the same for the piece of music to remain self-identical. At the same time, a piece of music cannot be substituted by any other work of art due to its uniqueness. A piece of music can exist in many ways. It is equally an artistic image, an author's conception, musical scores, a digital recording, a concert performance by a specific musician in a specific place and at a specific time. A piece of music is then realized in the muscular-intellectual memory enacted by a performer's motor skills. In this sense, people say about a pianist that Chopin's h-moll Sonata is "in his hands." And at first glance, nothing of the aforementioned is primary to other ways of the existence of music.

Few researchers are indifferent to the phenomenological problem of the relation between a piece of music and its performance. From Ingarden's point of view, the de- 
scribed contradictions are more than enough to admit an inconsistency in the efforts to equate a piece of music with its performance. Ingarden does, however, have some serious opposition to his position. Researchers' positions can be primarily divided into two poles: on one hand, we have Ingarden's interpretation, according to which the performance does not supplement the piece of music; on the other hand, we have a theory, according to which a piece of music and a performance are identical and equivalent. Merleau-Ponty was one of the first thinkers to articulate the latter position. He comprehends a piece of music via an analogy with the human body. Like our body, a work of music is individual, i.e. it is something in which an expression is indistinguishable from the thing expressed and its meaning, and which is accessible only through direct contact without any change in its temporal and spatial situation. It is a nexus of living meanings but not a law for a certain number of covariant terms (Merleau-Ponty, 2002, $175,212)$. Pryer holds to a more radical point by proposing to free performance from the "tyranny" of preexistent works, i.e. "dissolve the supposed hierarchy between work and performance" (Pryer, 2013, 200), which means that "there are no musical works as such, there are only musical performances" (Pryer, 2013, 212).

\section{INGARDEN'S INTERPRETATION \\ OF THE SPATIO-TEMPORAL MODUS OF THE EXISTENCE OF MUSIC}

According to the traditional phenomenological understanding of music, time is a duration constituted by consciousness, which is activated in a particular way and set in motion by audial experience. But musical time can also be comprehended as the time of objective being. D. Ihde holds this position when he claims that the temporal horizons of music are an indicator of time. According to Ihde, a sound reveals time (Ihde, 2007, 102). Ingarden suggests the third version: musical time is an independent kind of temporality.

We should notice that Ingarden's point of view proceeds from the line of argumentation started by Sartre in his work L'imaginaire: Psychologie phénoménologique de l'imagination written in 1940. At the end of his work, Sartre states the ideas which Ingarden would develop in The Work of Music and the Problem of its Identity.

To the extent that I grasp it, the symphony is not there, between those walls, at the tip of the violin bows. Nor is it "past" as if I thought: this is the work that took shape on such a date in the mind of Beethoven. It is entirely outside the real. It has its own time, which is to say it possesses an internal time, which flows from the first note of the allegro to the last note of the finale, but this time does not follow another time that it continues and that happened "before" the beginning of the allegro, nor is it followed by a time that 
would come "after" the finale. The Seventh Symphony is in no way in time. It therefore entirely escapes the real. (Sartre, 2004, 192)

Ingarden's theory of musical time is rightfully regarded as his most developed and influential contribution. By fixing the characteristic features of musical time, Ingarden is able to summarize his ontological and phenomenological viewpoints. According to Ingarden, musical time is:

1. Inseparable from the audial filling of its concrete moments, which constitute the basis of its being.

2. Not homogeneous as compared to the physical time of the performance of a piece of music.

3. Fractional and composed of units ("moments") that detachable from each other and which contain the principles of that detachment.

4. Hierarchical at all levels with precise segments ("cuts"), which nevertheless do not break the continuity of the piece.

5. Characterized by anticipating of the earlier phases before the later ones (from all appearances, this phenomenon is something of another order than protensions of temporal synthesis, i.e. primary anticipations of future in present).

6. Absolutely bilaterally completed, self-contained, and not included in the temporal continuum of the real world (Ingarden, 1986, 71-79).

Ingarden emphasized the following point after Sartre: if the finitude of any kind of object and process always implies a perspective of further temporal phases, the end of a symphony or a sonata does not open any musical, temporal perspective. Ingarden concludes that musical time is an organized quasi-time, which can be easily "integrated" into any other type of time, whether it is historical, physical, or mental. By its nature, a piece of music is beyond time and, therefore, can be performed at will at any moment. The same can be said about the spatial mode of the being of music. Thus, the spatiotemporal mode of the being of music does not correspond with any mode of being in Ingarden’s ontological system (Ingarden, 1987, $\$ \$ 27-29$ ). Musical existence is neither an object, nor a process nor an event. It has its own time and space.

\section{AN ONTOLOGICAL STATUS OF A WORK OF MUSIC}

Husserl identifies a specific feature of a piece of music which provides an important solution to the problem of its ontological status: works of music have no identity based on their spatiotemporal data (Husserl, 1973, 265-266). Though a work of music 
is always comprehended as a concrete real object correlated with the spatiotemporal conditions of its appearance, it may appear in different realities (things) as self-identical. Such specific features of music brought Husserl to assert the concept of the irreality of works of art. He characterized a piece of music as an ideal object and, for this purpose, brought in certain new, special notions such as "free" and "bound idealities" to light. To illustrate the notion of "bound idealities", he refers to word-types, and to illustrate the notion of free idealities that are not bound to the real world, he refers to numbers (Husserl, 1973, 267). To all appearances, music is to be related to "bound idealities," so long as we take into consideration that the notion of the "boundedness" (connectedness) of idealities requires further clarification.

From here, Husserl opens a wide field for understanding concerning how music is connected with reality: it may be an original musical score, it must be listened to, it may be performed, etc. The "bound" factor can be understood as a real denotation (like in the case of a word) and also as a spatiotemporal fixedness or a cultural context. According to Geniusas, musical works are bound idealities, which are inseparable from their reproductions. However, there is also a temporal aspect of their 'boundness': they do not have retroactive validity (Geniusas, 2018, 241). Geniusas suggests that we should understand free idealities as spiritual essences that are generated by human culture and the mind. But their correlate exists in the real world regardless of whether or not they are created. For instance, the law of gravity is a free ideality, because the effect of the law of gravity does not depend on its discovery. It already existed in antiquity even though it was not yet discovered. A work of music is a bound ideality. Its effect is possible only from the moment of its appearance and is only spread to later periods on the time scale. A work of music is not real, but ideal; nonetheless, its validity is not retroactive.

The conceptions of applied phenomenology and post-phenomenology developed from the second half of the $20^{\text {th }}$ century provide yet another point of view. They are aimed at revealing the mutual connection between phenomena and a perceiving subject (Ihde, 2003; Rose \& Wylie, 2006; Lea, 2009). In the context of phenomenology of music, this position should be understood from the point of view that music and a subject mutually constitute each other.

I intend, or tend-toward the object of feeling, but at the same time submit to it by allowing it to touch me. Possession itself is thus two-directional: I possess the music, and it possesses me. (Clifton, 1976, 76)

This tendency was developed under the influence of object-oriented ontology which negates any "privileged access point" to reality in a human consciousness. 
Post-phenomenology attempts to escape subject-centered classical phenomenological thought and, specifically, the Husserlian concept of the transcendental subject or ego. A subject as an agent of cognition is someone who is simultaneously under the influence of a given phenomenon and yet who is still responsible for that influence.

The affected subjectivity and its role as an intermediary and environment of phenomenolization becomes a field of phenomenological analysis. As a result, the phenomenological angle shifts and the emphasis on the analysis of music turns to its objectivity. This tendency was evident in the first generation of French phenomenologists. Thus, Sartre characterizes a symphony as follows: "It is evidently a thing, which is something that is before me, that resists, that endures" (Sartre, 2004, 192). Merleau-Ponty also describes a performance of a piece of organ music as the emancipation of music from an instrument and an organist's body (Merleau-Ponty, 2002, 168). Such "enslavement" of a listener or a performer carried out by music often attracts the attention of a phenomenologist as an important subject-matter of reflection.

The most radical version among such formulations of the ontological status of music is that of Don Ihde, who does not draw a boundary between musical and unmusical sounds: "There is a fundamental sense in which the sounds of the world are the first music, with what we call music in a narrower sense as a kind of abstracting from this auditory realm" (Ihde, 2007, 191). Thus, according to D. Ihde, music does not exist as an individual phenomenon, but is simply a particular case of the reality of objective sound.

\section{INGARDEN'S VERSION OF THE ONTOLOGICAL STATUS OF A WORK OF MUSIC}

Ingarden does not adhere to any of the foregoing positions in his solution to the problem of the ontological status of a piece of music. Ingarden's key question is as follows: "As for the musical work that is neither physical nor mental (surely not a conscious experience or any part of it) [...], how can it 'await' our perceptions and manifest itself to us as exactly the same?" (Ingarden, 1986, 3).

Certain aspects of the existence of a work of music are important to him: a) its unreality; b) the heteronomy of its existence; c) its supratemporal and supraspatial nature; and d) its self-sufficiency, i.e. that the sphere of musical and audial forms does not require anything except itself for music to be an intentional correlate.

Conforming to Husserl's principles, Ingarden insists on the transcendence of a piece of music; moreover, he considers the transcendence of music to be multi-layered. The first layer is the transcendence of an opus in relation to its performers. The 
fact that a work of music is outside of conscious experiences and listeners' perceptions constitutes the next layer of transcendence (Ingarden, 1986, 33). The ontology of a piece of music is connected with its unique individuality, defined by Ingarden as its purely qualitative, undetermined and spatiotemporal definiteness. In spite of its uniqueness, a piece of music exists in all of its performances and therefore has a supraindividual and supratemporal nature.

Finally, instrumental and non-programmatic music, which Ingarden calls "pure" and "absolute," does not have any equivalent in the real world.

The world of sound-constructs and the edifices built upon them forms a distinct realm. Every work forms an ideally self-contained whole, not related to the real world either through its sound material, through the gestalt of sound-constructs of a higher order, or through its quasitemporal structure. (Ingarden, 1986, 82)

What should a piece of music be, from an ontological point of view, to correspond to all of the aforementioned points? The solution to the problem lies in treating a piece of music as a purely intentional object.

Ingarden borrows the term "intentional object" from Husserl. By intentional object, Husserl means any object or state of affairs of an act, regardless of whether the object is real, unreal, fictitious or absurd. An intentional object need not be a concrete material thing in its givenness but can be a number or the Roman god Jupiter (Husserl, 1901, 352-353). An intentional object is only perceived but not really experienced. Rather, as Moran and Cohen notice, even fictional objects are transcendent above our mental experiences, intentional experience always transcends itself towards the object, its character is a "pointing beyond itself towards" (über sich hinausweisen) something (Moran \& Cohen, 2012 , 216). This means that the object is given in an act of feeling but does not form a part of the very same act as a piece of music does in Ingarden's description, which is experienced in perception but does not constitute any part of a listener's mental life.

Ingarden comprehends an intentional object as a special kind of correlation between a certain conscious process that corresponds to an ordered process of experience. Such an object is constituted by means of consciousness and from consciousness, but as if it is objectified in relation to consciousness. It is important that an intentional object is always transcendental to an act of consciousness. Therefore, according to Husserl, the world can never become an experience of a person who reflects upon it. An experience is an affirmation of the world but that world is an identified object (Husserl, 1901, 365).

One would think that the notion of the "intentional object" consists precisely in all those things, that brought Husserl to transcendental idealism, and that Ingarden did 
not accept. (Ingarden, 1975). An intentional object can be construed as a marker of the inaccessibility of the world to a subject. Furthermore, this notion is entirely epistemological and it liberates the matter from ontological obligations. Husserl is not concerned with whether or not an intentional object exists or how it exists. An intentional object is simply a subject of possible predications that exist in an act. Therefore, strictly speaking, a definition of a piece of music as an intentional object is not a definition of its ontological status. Nevertheless, Ingarden insists on this particular definition.

We should compile all of Ingarden's reflections on music in order to understand why he does not define a piece of music in some other way. According to Ingarden, pieces of music are not real, i.e. they are neither material nor ideal; they are neither things, nor processes, nor events. Here Ingarden's position stands aside from other phenomenological accounts. From his point of view, a work of art of any kind is neither a real thing nor an object independent in its existence. It differs by certain principled existential relativity which cannot be eliminated in any other kind of art (Ingarden, 1958, 267). Every work of art fundamentally differs from the real thing in which it has its existential basis. Meanwhile, it does not depend on the qualities of its existential correlates, in particular the qualities of its "material." In this regard, it is similar to Husserl's "bound ideality."

From the perspective of being, a piece of music is relative and heteronomous but its existential relativity is not one-sided as a work of art has a reciprocal effect on real things. A work of music affects its composer and his psychophysical acts; it also influences the psychophysical acts, known as the "aesthetic experience," of listeners. Since a piece of music as a purely intentional object is intersubjectively available, it must be the same object for many various psychophysical subjects. In this respect, it exists on the basis of its concreteness, i.e. real musical scores, recordings and performances (Ingarden, 1986, 121-122).

The comprehension of a piece of music as an intentional object coherently explains why music is impossible without its sounding, performance, musical scores, a composer, and a listener, while it is not synonymous with any of these elements. A work of music is an intentional object; that is, an object represented by something given concretely. In contrast to the other kinds of art, its principle of being is such that in the process of perception one may not exceed the sphere of the concretely given, i.e. the sphere of musical sound formations to create a totally new intentional object on this basis. According to Ingarden, this feature of music is akin only to architecture. Both in music and architecture there is an immediate grasp of the given in visual or auditory perception which immediately and without any intermediaries "brings" a contemplating person to a work of art (Ingarden, 1958). 
Evidently, Ingarden herein refers to moments of the substance of art. In most kinds of art, painted "views" and verbal forms refer to an extraneous layer of being, i.e. to the things as depicted or designated by words. It is impossible to constitute the intentional objectivity of a picture, a sculpture or a poem without passing to that layer. Meanwhile, music and architecture are completely restricted by the sphere of the concretely given, i.e. sound or geometric forms and their relations. Appealing to Sartre's words, "a melody refers to nothing but itself" (Sartre, 2004, 191).

Finally, Ingarden's argument is ultimately a complex solution to the problem of what identifies something as a piece of music. No matter how one solves this problem, the very complexity of its solution shows that we are not faced with some particular real thing but an ideal boundary to which all intentional purposes of creative acts of a composer or perceptual acts of a listener are directed; that is, a completely intersubjective intentional object of a higher order (Ingarden, 1986, 119).

\section{CONCLUSION: DISCUSSIONS AND PERSPECTIVES}

By the moment Ingarden wrote The Work of Music and the Problem of its Identity, he had already completed his mature conception of aesthetics and disseminated it to the world. On one hand, Ingarden's interpretation of a piece of music continued his endeavor to comprehend the work of art. On the other hand, it combined all the elements of his phenomenology and resolved the key problem of the identity of a piece of music.

Ingarden's aesthetics of music became one of the essential "growth points" in phenomenology of music which inspired further reflections by other thinkers and revealed altogether new branches of study.

The features of Ingarden's methodology show that many of his theses exceed the sphere of pure phenomenology. They stretch even to the sphere of musical culture and thus become assailable for critique (Pytlak, 1989). It is obvious that Ingarden's analysis of a piece of music cannot be extended to many other musical phenomena. One may point to improvisational styles like jazz, a technique of partially controlling a musical score, and aleatory music, to call into doubt Ingarden's thesis that a piece of music is not its performance and that performance does not add anything to a piece of music.

From Ingarden's point of view, a piece of music is not at all synonymous with its performance, as performance is not an acoustic process and a piece of music is not an acoustic phenomenon (Ingarden, 1986, 10). A work of music does not cease to exist in the moments when it sounds. But works of the forms of music mentioned above exist in their uniqueness only when they sound. A new performance brings about 
new forms of sound. Moreover, Ingarden's argumentation is undermined by musique concrete $^{1}$, as a recording of certain sound forms, both noise and musical ones. Such a work only exists as a recording on a certain device. It means that there is not any performance for a concrete work of music and a composer does not fix it in scores. Consequently, it does not have its invariant and the ideal bound of intentional purposes, i.e. the intentional objectivity discussed by Ingarden. We also cannot agree that the incompleteness of musical scores shows that every piece of music is just a scheme signifying the plurality of its potential concrete forms. Ingarden believes that every musical score has its own gaps and moments of incomplete designation which provide a good reason to consider a piece of music designated by musical scores as a purely intentional object (Ingarden, 1986, 117, 152). In fact, if it is not aleatory music, it is difficult to imagine what kind of gaps traditional or modern musical scores have. Naturally, there can be some insignificant dynamic, agogic, and tempo-based fluctuations though the latter may exist only if a composer does not provide any metronomic indications. From the time of Beethoven, all nuances have been thoroughly fixed, leaving no freedom for a performer whether it is in the form of strokes, phrasing, accentuation, character of the performance, pedaling technique for piano music or bow direction for violin musical scores. Modern composers' musical scores are preceded by dozens of sheets of transcription of the elements of notation and performance directives to be given by a composer. Ingarden's comprehension of musical scores as an incomplete and imperfect way of music fixation cannot be verified in musical practice. Consequently, there is an underestimation of the value of musical scores and signifying intention for an identity of a piece of music.

The question also remains as to whether Ingarden's study of music achieves the aim he sets out in the title of his work. According to Ingarden, a piece of music is an intersubjective and intentional object, the identity of which cannot be expressed in a simple statement. Nevertheless, here is Ingarden's conclusion as to what he considers to be the source of the purely qualitative individuality of a piece of music. He sees it as a singular correlation between the moments of time immanent to a piece of music and sounding musical formations, which gives rise to a unique quasi-temporal structure.

The originality of Ingarden's method is connected with the fact that he is not directly interested in the sounding matter of music. He is interested in the cognition of music as an absolutely quasi-temporal intentional object without any equivalent

1 It is remarkable that L. Ferrara chooses one piece of music from musique concrète, Edgar Varèse's Poème électronique written in 1958 (Ferrara, 1984) to demonstrate his phenomenological procedure. It means that the ideas of music phenomena and aims of phenomenology of music had changed by the end of the $20^{\text {th }}$ century. 
in the real world and without any essential connection with it altogether (Ingarden, $1986,82)$. But in spite of the richness of his analysis, the main object of consideration of all of Ingarden's reasoning and the key argument of his theses is the specific feature of musical time. Here Ingarden demonstrates his talent for phenomenology and determines analytical steps for further interpretations. Thus, for instance, he pays attention to the point that performance is a process during which all parts of a piece of music follow one after another in a certain consecution of temporal phases. Parts of a piece of music exist simultaneously, preserving some specific "order of consecution" (Ingarden, 1986, 16). This part of Ingarden's thesis is to be understood as follows: a piece of music in its unsounding aspect is some kind of plan or a scheme. It exists in musical scores or in a performer's memory simultaneously in of all its phases. As long as music does not sound, its time is "rolled up."

There appears a perspective which allows us to determine a number of the essential peculiarities of how musical time unfolds. If we call to mind a melody, we may begin to sing it aloud or in our mind. Then the musical time of a melody, having been rolled up earlier, begins to unfold in its "original scale," slightly varying in accordance with tempo but maintaining an invariant structure of rhythmic and altitudinal relations. It is worth mentioning that we are not able to bring about a melody unless we initiate its immanent procession in time and 'superimpose' it on the time of physical and psychic processes. This means that at mental and audial levels, musical time unfolds in different modes; also, mental time is not audial. Eventually, the study of these two musical modes of time clarifies the temporal aspects of embodied mind and discovers the principles of the interaction between consciousness and the body. This is one of many possible examples of the perspectives opened by Ingarden's ideas.

The further development of phenomenology of music has marked a withdrawal of the notion that music is purely intentional and entirely a transcendental correlate of acts of consciousness. The emphasis went from a fixation on conscious perception and analysis of constitutive acts to a fixation on physical intentions, emotional states, constituting of intersubjective correlates and eventful and cultural contexts of music experience. The concept of 'embodied cognition' has become a topical matter in contemporary phenomenological studies. Analysis of the interaction between corporeal nature and sound is of great importance (Clifton, 1983; Brown, 2006; Welten, 2009; $\mathrm{Siu}, 2016)$. This trend is of great interest in applied musical phenomenological studies oriented towards psychological, therapeutic, media-based and educational practices (Adorno, 2006; Christensen, 2012, etc.). It is hard to overestimate the significance of Roman Ingarden's contribution to phenomenology of music in the context of new trends. He left the fundamental work of comprising patterns of classical procedures of 
phenomenological analysis to later generations. At the same time, The Work of Music and the Problem of its Identity opens new vectors in the development of phenomenology of music starting from the emancipation and objectification of music to opening the way for interdisciplinary approach to the matter though a synthesis of phenomenology and other sciences.

\section{REFERENCES}

Adorno, T. W. (2006). Current of Music: Elements of a Radio Theory (R. Hullot-Kentor, Ed.). Frankfurt am Main: Suhrkamp.

Brown, N. (2006). The Flux Between Sounding and Sound: Towards a Relational Understanding of Music as Embodied Action. Contemporary Music Review, 25 (1), 37-46.

Christensen, E. (2012). Music Listening, Music Therapy, Phenomenology and Neuroscience. Aalborg University, Denmark. Retrieved from http://www.mt-phd.aau.dk/phd-theses

Clifton, T. (1976). Music as Constituted Object. Music and Man, 2, 73-98.

Clifton, T. (1983). Music as Heard: A Study in Applied Phenomenology. New Haven: Yale University Press.

Conrad, W.(1908). Der ästhetische Gegenstand. Zeitschrift für Ästhetik und allgemeine Kunstwissenschaft, 3, 71-118.

Dufrenne, M. (1953). Phenomenologie de l'experience esthétique. Paris: Press universitaires de France.

Ferrara, L. (1984). Phenomenology as a Tool for Musical Analysis. Musical Quarterly, 70 (3), 355-373.

Geniusas, S. (2018). Musical Works as Ideal Objects: Phenomenology of Music and its Implications for Philosophical Anthropology. Dialogue and Universalism, 28 (4), 231-244.

Husserl, E. (1901). Logische Untersuchungen. Zweiter Teil: Untersuchungen zur Phänomenologie und Theorie der Erkenntnis. Halle: Max Niemeyer.

Husserl, E. (1973). Experience and Judgment. Investigations in a Genealogy of Logic. Evanston: Northwestern University Press.

Husserl, E.(1980). Phantasie, Bildbewußtsein, Erinnerung. Zur Phänomenologie der anschaulichen Vergegenwärtigungen. Texte aus dem Nachlass (1898-1925) (E. Marbach, Ed.). The Hague: Martinus Nijhoff Publishers.

Ihde, D. (2003). Postphenomenology - Again? Working Paper No. 3, Centre for STS Studies, Aarhus University Denmark, 3-25.

Ihde, D. (2007). Listening and Voice. Phenomenologies of Sound (2nd ed.). Albany, NY: State University of New York Press.

Ingarden, R. (1955). Elementy dzieła muzycznego. Sprawozdania Towarzystwa Naukowego w Toruniu, $9(1-4), 82-84$.

Ingarden, R. (1958). Studia z estetyki. Vol. II. Warszawa: Państwowe Wydawnictwo Naukowe.

Ingarden, R.(1962). Untersuchungen zur Ontologie der Kunst: Musikwerk. Bild. Architektur. Film. Tübingen: Max Niemeyer.

Ingarden, R. (1973). Utwór muzyczny i sprawa jego tożsamości. Warszawa: Polskie Wydawnictwo Muzyczne.

Ingarden, R. (1975). On the Motives Which Led Husserl to Transcendental Idealism. The Hague: Martinus Nijhoff.

Ingarden, R. (1986). The Work of Music and the Problem of its Identity (A. Czerniawski, Trans.; J. G. Harrell, Ed.). Oakland: University of California Press. 
Ingarden, R. (1987). Spór o istnienie Świata. Vol. I: Ontologia egzystencjalna. Warszawa: Państwowe Wydawnictwo Naukowe.

Kocay, V.(2002). Roman Ingarden's Unique Conception of Aesthetic Objects. In A.-T. Tymieniecka (Ed.), Phenomenology World-Wide. Analecta Husserliana, Vol. 80 (202-210). Dordrecht: Springer.

Lea, J. (2009). Post-Phenomenology. Post-phenomenological Geographies. In R. Kitchen, \& N. Thrift (Eds.), International Encyclopaedia of Human Geography (373-378). London: Elsevier.

Lochhead, J. (1986). Temporal Structure in Recent Music. Journal of Musicological Research, 6, 49-93.

Merleau-Ponty, M. (1962). Phenomenology of Perception (C. Smith, Trans.). London: Routledge \& Kegan Paul.

Merleau-Ponty, M. (2002). Phenomenology of Perception (2nd ed.). London: Routledge Classics.

Mitscherling, J. (2012). Roman Ingarden's Aesthetics Philosophy. Compass, 7 (7), 436-447.

Moran, D., \& Cohen, J.(2012). The Husserl Dictionary. Continuum Philosophical Dictionaries. London: Continuum.

Pryer, A. (2013). The Ontology of Music and the Challenge of Performance: Identity versus Variety, and the Persistence of the "Text". In T. Makel, \& T. Klein (Eds.), The Embodiment of Authority: Perspectives on Performance (100-214). Frankfurt: Peter Lang.

Pytlak, A. (1989) On Ingarden's Conception of the Musical Composition. In B. Dziemidok, \& P. McCormick (Eds.), On the Aesthetics of Roman Ingarden: Interpretations and Assessments (233-254). Dordrecht: Kluwer Academic Publishers.

Rose, M., \& Wylie, J. (2006). Animating Landscape. Environment and Planning D. Society and Space, $24,475-479$.

Sartre, J.-P. (1940). L'imaginaire: Psychologie phénoménologique de l'imagination. Paris: Gallimard.

Sartre, J.-P.(2004). The Imaginary: A Phenomenological Psychology of the Imagination (J. Webber, Trans.). London \& New York: Routledge.

Schütz, A. (1976). Fragments on the Phenomenology of Music. Music and Man, 2, 5-71.

Siu, R. C. (2016). Rethinking the Body and Space in Alfred Schutz's Phenomenology of Music. Human Studies, 39, 533-546.

Smith, F. J. (1973). Musical Sound as a Model for Husserlian Intuition and Time-Consciousness. Journal of Phenomenological Psychology, 4, 271-296.

Sodeika, T. (1989). The Ingarden-Husserl Controversy: The Methodological Status of Consciousness in Phenomenology and the Limits of the Human Condition. In A.-T. Tymieniecka (Ed.), Man Within His Life World: Contributions To Phenomenology By Scholars From East Central Europe (209-221). Dordrecht: Springer Science \& Business Media.

Welten, R. (2009). What Do We Hear When We Hear Music? A Radical Phenomenology of Music. Studia Phaenomenologica, 9, 269-286. 